\title{
PENERAPAN PEMBELAJARAN KOOPERATIF TIPE NUMBERED HEADS TOGETHER (NHT) UNTUK MENINGKATKAN KEMAMPUAN KOMUNIKASI MATEMATIS DAN SELF-EFFICACY SISWA KELAS VIII MTS YKWI PEKANBARU
}

\author{
Putri Wahyuni ${ }^{a}$, Fitriana Yolanda ${ }^{b}$ \\ aProgram Studi Pendidikan Matematika FKIP UIR \\ Jl. Kaharuddin Nasution no 113 Perhentian Marpoyan, wahyuniputri@edu.uir.ac.id \\ ${ }^{\text {b}}$ Program Studi Pendidikan Matematika FKIP UIR \\ Jl. Kaharuddin Nasution no 113 Perhentian Marpoyan, fitrianayolanda@edu.uir.ac.id
}

\begin{abstract}
ABSTRAK
Penelitian ini bertujuan untuk meningkatkan kemampuan komunikasi dan self-efficacy siswa melalui Penerapan Pembelajaran Kooperatif Tipe Numbered Heads Together (NHT). Penelitian ini merupakan penelitian tindakan kelas dengan subjek siswa kelas VIII MTs YKWI Pekanbaru Tahun Ajaran 2016/2017 pada materi relasi dan fungsi. Teknik pengumpulan data pada penelitian ini adalah dengan menggunakan lembar pengamatan, angket dan tes. Hasil penelitan ini menunjukkan bahwa terjadi peningkatan kemampuan komunikasi dan self-efficacy siswa dari skor dasar ke UH I, dari UH I ke UH II. Persentase kemampuan komunikasi matematika siswa pada skor dasar adalah $36,87 \%$, pada UH I adalah $47,5 \%$ dan pada UH II adalah $72,81 \%$. Sedangkan self-efficacy siswa pada UH 1 $54,6 \%$ dan pada UH II 77,2\%. Berdasarkan hasil penelitian ini, maka dapat disimpulkan bahwa penerapan pembelajaran kooperatif tipe Numbered Heads Together (NHT) dapat meningkatkan kemampuan komunikasi dan self-efficacy siswa kelas VIII MTs YKWI Pekanbaru Tahun Ajaran $2016 / 2017$.
\end{abstract}

Kata Kunci: NHT, Kemampuan Komunikasi dan self-efficacy siswa.

\begin{abstract}
This study aims to improve communication skills and student self-efficacy through the Application of Numbered Heads Together (NHT) Cooperative Learning. This research is a classroom action research with the subject of class VIII YKWI MTs Pekanbaru 2016/2017 Academic Year on material relations and functions. Data collection techniques in this study were using observation sheets, questionnaires and tests. The results of this study indicate that there is an increase in communication skills and self-efficacy of students from the basic score to UH I, from UH I to UH II. The percentage of students' mathematical communication skills in the basic score was $36.87 \%$, in UH I was $47.5 \%$ and in UH II was $72.81 \%$. While students' self-efficacy in UH 1 was $54.6 \%$ and in UH II was $77.2 \%$. Based on the results of this study, it can be concluded that the application of Numbered Heads Together (NHT) type of cooperative learning can improve communication skills and self-efficacy of class VIII YKWI MTs Pekanbaru Academic Year 2016/2017.
\end{abstract}

Keywords: NHT, Communication Ability and student self-efficacy.

Pendahuluan

Kemampuan komunikasi

matematika merupakan salah satu

kemampuan yang harus dimiliki oleh siswa setelah belajar matematika. Oleh sebab itu kemampuan komunikasi matematika dirasakan perlu mendapat perhatian untuk lebih dikembangkan. 
Kemampuan komunikasi matematika merupakan kemampuan yang diperlukan dalam belajar matematika dan sangat diperlukan dalam menghadapi masalah dalam kehidupan siswa. Namun kenyataannya sebagian besar kemampuan komunikasi siswa masih rendah. Sudah menjadi rahasia umum bahwa pelajaran matematika dikenal sebagai mata pelajaran yang sulit bagi siswa. Sehingga matematika menjadi mata pelajaran yang kurang disukai siswa. Apalagi jika penyajian guru dalam menyampaikan materi pelajaran kurang menarik perhatian siswa. Hal ini akan menambah kesulitan siswa dalam belajar matematika.

Berdasarkan hasil observasi dan wawancara yang peneliti lakukan di MTs YKWI Pekanbaru pada tanggal 4 April 2016, menyatakan bahwa kegiatan pembelajaran matematika masih banyak didominasi oleh aktivitas guru, dan guru kurang dalam memberikan soal yang berhubungan dengan komunikasi matematis kepada siswa. Hal ini dapat dilihat ketika guru memberikan soal yang berhubungan dengan soal komunikasi matematis. Dari tes yang diberikan, diperoleh bahwa hanya 28,5\% siswa yang mampu menjawab soal komunikasi matematis. Hal ini menunjukkan bahwa komunikasi matematika siswa masih kurang. Kurangnya pemahaman siswa terhadap konsep-konsep yang terdapat dalam matematika dan masih sulitnya siswa berkomunikasi secara matematis. Hal ini dikarenakan guru pada waktu mengajar belum menggunakan metode pembelajaran yang dapat mendorong siswa berpikir dan melibatkan siswa secara aktif. Masih banyak guru dalam mengajar menggunakan metode pembelajaran secara konvensional, yaitu suatu metode pembelajaran yang berpusat pada guru. Rendahnya kemampuan komunikasi matematis, tidak lepas dari proses pembelajaran matematika. Peningkatan kemampuan komunikasi siswa dapat dilakukan dengan merancang suatu pembelajaran yang membiasakan siswa untuk mengkonstruksi sendiri pengetahuannya, sehingga siswa lebih memahami konsep yang diajarkan serta mampu mengkomunikasikan pemikirannya baik dengan guru, teman maupun terhadap materi matematika itu sendiri serta mampu memecahkan masalah-masalah matematika. Selain kemampuan komunikasi matematis, terdapat aspek lain yang menunjang proses pembelajaran matematika siswa yaitu aspek psikologis yang salah satunya adalah self-efficacy.

Self-efficacy mampu meningkatkan kemampuan matematika siswa melalui usaha untuk membangun keyakinan diri seseorang untuk mencapai kesuksesan dalam menyelesaikan 
permasalahan dalam kehidupan. Selfefficacy memiliki pengaruh dalam pemilihan perilaku, besar usaha dan ketekunan, serta pola berpikir dan reaksi emosional. Penilaian self-efficacy mendorong individu menghindari situasi yang diyakini melampaui kemampuannya atau melakukan kegiatan yang diperkirakan dapat diatasinya. Dalam memecahkan masalah yang sulit, individu yang mempunyai keraguan tentang kemampuannya akan mengurangi usahanya bahkan cenderung akan menyerah. Perlu diperhatikan bahwa keyakinan diri yang dipersepsikan seseorang memainkan peranan kunci dalam kehidupan manusia, karena hal tersebut memberi pengaruh pada perilaku manusia secara keseluruhan seperti kepercayaan, emosi, pemikiran dan tindakan (Ilhamsyah, 2014:15). Siswa yang memiliki selfefficacy rendah akan cenderung ragu-ragu dalam penyelesaian masalah matematika. Sebaliknya siswa yang memiliki selfefficacy tinggi akan sangat yakin dengan yang akan dikerjakannya. Salah satu model pembelajaran yang diharapkan dapat mengembangkan kemampuan komunikasi dan self-efficacy siswa adalah model pembelajaran kooperatif. Dengan pembelajaran kooperatif siswa dapat berkomunikasi dengan temannya dan saling membantu untuk memecahkan masalah bersama. Model pembelajaran kooperatif terdiri dari berbagai macam model. Namun pembelajaran yang akan digunakan dalam penelitian ini adalah model pembelajaran kooperatif tipe Numbered Heads Together (NHT).

Berdasarkan uraian di atas, peneliti berharap pembelajaran kooperatif tipe Numbered Heads Together (NHT) dapat meningkatkan kemampuan komunikasi matematis dan self-efficacy siswa. Dengan demikian peneliti tertarik untuk melakukan penelitian yang berjudul "Penerapan Pembelajaran Kooperatif Tipe Numbered Heads Together (NHT) Untuk Meningkatkan Kemampuan Komunikasi Matematis dan Self-Efficacy Siswa Kelas VIII Mts YKWI Pekanbaru”.

Adapun rumusan masalah dalam penelitian ini adalah apakah penerapan pembelajaran kooperatif tipe Numbered Head Together (NHT) dapat memperbaiki proses pembelajaran dan meningkatkan kemampuan komunikasi matematis serta self-efficacy siswa kelas VIII Mts YKWI Pekanbaru 2016/2017. Sedangkan tujuan penelitian ini yaitu untuk memperbaiki proses pembelajaran dan meningkatkan kemampuan komunikasi matematis serta self-efficacy siswa kelas VIII Mts YKWI Pekanbaru melalui penerapan pembelajaran kooperatif tipe Numbered Head Together (NHT) 


\section{Metode Penelitian}

Bentuk penelitian ini adalah Penelitian Tindakan Kelas (PTK). Penelitian Tindakan Kelas (PTK) memiliki peranan yang sangat penting dan strategis untuk meningkatkan mutu pembelajaran apabila diimplementasikan dengan baik dan benar (Kunandar, 2010:41). Dalam pelaksanaan penelitian tindakan kelas ini akan dilakukan dua siklus. Menurut Arikunto (2012 : 74), Penelitian tindakan kelas ini terdiri atas rangkaian empat kegiatan yang dilakukan dalam siklus berulang. Empat kegiatan utama yang ada pada setiap siklus, yaitu (a) perencanaan, (b) pelaksanaan, pengamatan dan (d) refleksi.

Penelitian Tindakan Kelas ini dilaksanakan di kelas VIII MTS YKWI Pekanbaru dari tanggal 4 oktober 2016 sampai 27 oktober 2016. Dengan Subjek dalam penelitian ini adalah siswa kelas VIII MTS YKWI Pekanbaru semester ganjil yang berjumlah 20 orang siswa.

Data tentang aktivitas guru dan siswa selama proses pembelajaran dikumpulkan dengan menggunakan tindakan perbaikan pada siklus berikutnya.

\section{2) Analisis Ketercapaian Komunikasi Matematis Siswa}

Untuk melihat kemampuan komunikasi matematis siswa dari soal lembar pengamatan, sedangkan data kemampuan komunikasi matematis siswa dan self-efficacy siswa dikumpulkan dengan menggunakan tes hasil belajar matematika dan angket. Tes dan angket diberikan pada ulangan harian I dan ulangan harian II.

Teknik analisis data yang digunakan adalah analisis statistik deskriptif. Analisis statistik deskriptif ini bertujuan untuk menggambarkan data tentang aktivitas siswa dan guru selama proses pembelajaran, data tentang komunikasi matematis dan self-efficacy siswa.

\section{1) Analisis Hasil Pengamatan}

Hasil pengamatan yang diperoleh pengamat dan peneliti dari lembar pengamatan dianalisis secara deskriptif atau uraian yang bertujuan untuk menggambarkan data tentang aktivitas guru dan siswa. Hasil pengamatan berguna untuk melihat kesesuaian antara perencanaan dengan pelaksanaan tindakan. Apabila dari hasil pengamatan tersebut masih terdapat kekeliruan atau ketidaksesuaian dalam pelaksanaan yang diberikan yang berbentuk soal kemampuan komunikasi matematis pada siklus 1 dan siklus 2, dapat dilakukan dengan melihat jawaban siswa dengan menggunakan kriteria skor kemampuan 
komunikasi matematis siswa seperti tabel

berikut ini :

Tabel 1: Rubrik Kemampuan Komunikasi Matematis

Indikator 0 2

3

4

\begin{tabular}{|c|c|c|c|c|c|}
\hline $\begin{array}{l}\text { 1.Menyajikan } \\
\text { pernyataan } \\
\text { matematika } \\
\text { secara tulisan } \\
\text { dan gambar }\end{array}$ & $\begin{array}{l}\text { Tidak } \\
\text { ada } \\
\text { jawaban }\end{array}$ & $\begin{array}{l}\text { Ada } \\
\text { jawaban, } \\
\text { tetapi } \\
\text { tidak } \\
\text { sesuai } \\
\text { kriteria }\end{array}$ & $\begin{array}{l}\text { Terdapat } \\
\text { banyak } \\
\text { kesalahan } \\
\text { dalam } \\
\text { penyelesaian } \\
\text { /tidak sesuai } \\
\text { dengan } \\
\text { kriteria, } \\
\text { namun hasil } \\
\text { akhirnya } \\
\text { benar }\end{array}$ & $\begin{array}{l}\text { Jawaban } \\
\text { benar, } \\
\text { sesuai } \\
\text { dengan } \\
\text { kriteria } \\
\text { tetapi } \\
\text { terdapat } \\
\text { sedikit } \\
\text { kesalahan } \\
\text { dalam } \\
\text { penulisan }\end{array}$ & $\begin{array}{l}\text { Jawaban benar, } \\
\text { mampu } \\
\text { menghubungkan } \\
\text { benda nyata, } \\
\text { gambar, dan } \\
\text { diagram ke } \\
\text { dalam } \\
\text { matematika }\end{array}$ \\
\hline $\begin{array}{l}\text { 2.Menjelaskan } \\
\text { ide secara } \\
\text { tulisan } \\
\text { dengan } \\
\text { gambar }\end{array}$ & $\begin{array}{l}\text { Tidak } \\
\text { ada } \\
\text { jawaban }\end{array}$ & $\begin{array}{l}\text { Ada } \\
\text { jawaban, } \\
\text { tetapi } \\
\text { tidak } \\
\text { sesuai } \\
\text { kriteria }\end{array}$ & $\begin{array}{l}\text { Terdapat } \\
\text { banyak } \\
\text { kesalahan } \\
\text { dalam } \\
\text { penyelesaian } \\
\text { /tidak sesuai } \\
\text { dengan } \\
\text { kriteria, } \\
\text { namun hasil } \\
\text { akhirnya } \\
\text { benar }\end{array}$ & $\begin{array}{l}\text { Jawaban } \\
\text { benar, } \\
\text { sesuai } \\
\text { dengan } \\
\text { kriteria } \\
\text { tetapi } \\
\text { terdapat } \\
\text { sedikit } \\
\text { kesalahan } \\
\text { dalam } \\
\text { penulisan }\end{array}$ & $\begin{array}{l}\text { Jawaban benar, } \\
\text { mampu } \\
\text { menjelaskan ide } \\
\text { situasi dan relasi } \\
\text { matematika } \\
\text { secara lisan atau } \\
\text { tulisan dengan } \\
\text { benda nyata, } \\
\text { gambar, grafik, } \\
\text { dan aljabar }\end{array}$ \\
\hline $\begin{array}{l}\text { 3.Menyatakan } \\
\text { peristiwa } \\
\text { sehari-hari } \\
\text { dalam bahasa } \\
\text { atau simbol } \\
\text { matematika }\end{array}$ & $\begin{array}{l}\text { Tidak } \\
\text { ada } \\
\text { jawaban }\end{array}$ & $\begin{array}{l}\text { Ada } \\
\text { jawaban, } \\
\text { tetapi } \\
\text { tidak } \\
\text { sesuai } \\
\text { kriteria }\end{array}$ & $\begin{array}{l}\text { Terdapat } \\
\text { banyak } \\
\text { kesalahan } \\
\text { dalam } \\
\text { penyelesaian } \\
\text { /tidak sesuai } \\
\text { dengan } \\
\text { kriteria, } \\
\text { namun hasil } \\
\text { akhirnya } \\
\text { benar }\end{array}$ & $\begin{array}{l}\text { Jawaban } \\
\text { benar, } \\
\text { sesuai } \\
\text { dengan } \\
\text { kriteria } \\
\text { tetapi } \\
\text { terdapat } \\
\text { sedikit } \\
\text { kesalahan } \\
\text { dalam } \\
\text { penulisan }\end{array}$ & $\begin{array}{l}\text { Jawaban benar, } \\
\text { mampu } \\
\text { menyatakan } \\
\text { peristiwa sehari- } \\
\text { hari dalam } \\
\text { bahasa atau } \\
\text { simbol } \\
\text { matematika }\end{array}$ \\
\hline $\begin{array}{l}\text { 4. Menghubung } \\
\text { kan gambar } \\
\text { ke dalam ide } \\
\text { matematika }\end{array}$ & $\begin{array}{l}\text { Tidak } \\
\text { ada } \\
\text { jawaban }\end{array}$ & $\begin{array}{l}\text { Ada } \\
\text { jawaban, } \\
\text { tetapi } \\
\text { tidak } \\
\text { sesuai } \\
\text { kriteria }\end{array}$ & $\begin{array}{l}\text { Terdapat } \\
\text { banyak } \\
\text { kesalahan } \\
\text { dalam } \\
\text { penyelesaian } \\
\text { /tidak sesuai } \\
\text { dengan } \\
\text { kriteria, } \\
\text { namun hasil } \\
\text { akhirnya } \\
\text { benar }\end{array}$ & $\begin{array}{l}\text { Jawaban } \\
\text { benar, } \\
\text { sesuai } \\
\text { dengan } \\
\text { kriteria } \\
\text { tetapi } \\
\text { terdapat } \\
\text { sedikit } \\
\text { kesalahan } \\
\text { dalam } \\
\text { penulisan }\end{array}$ & $\begin{array}{l}\text { Jawaban benar, } \\
\text { mampu } \\
\text { menyatakan } \\
\text { peristiwa sehari- } \\
\text { hari dalam } \\
\text { bahasa atau } \\
\text { simbol } \\
\text { matematika }\end{array}$ \\
\hline
\end{tabular}


Sumber:Diadaptasi dari Fauzan (2012:15)

Cara menghitung persentase

komunikasi matematis siswa dan

kualifikasi persentase komunikasi

matematis siswa dimodifikasi dari

Prasetya (dalam Rahayu, 2014:29) adalah

sebagai berikut:

Persentase skor jawaban = $=\frac{\text { Skor jawaban yang benar }}{\text { skor maksimal }} \times 100 \%$

Tabel 2: Kualifikasi Persentase Kemampuan Komunikasi Matematis Siswa

$\begin{array}{ccc}\text { No } & \text { Persentase } & \text { Kriteria } \\ 1 & 80 \% \leq \mathrm{P} \leq 100 \% & \begin{array}{c}\text { Sangat } \\ \text { Tinggi }\end{array} \\ 2 & 60 \% \leq \mathrm{P}<80 \% & \text { Tinggi } \\ 3 & 40 \% \leq \mathrm{P}<60 \% & \text { Cukup } \\ 4 & 20 \% \leq \mathrm{P}<40 \% & \text { Rendah } \\ 5 & \mathrm{P}<20 \% & \begin{array}{c}\text { Sangat } \\ \text { Rendah }\end{array}\end{array}$

\section{3) Analisis Self-Efficacy Siswa}

Peningkatan self-efficacy siswa dapat dilihat dari hasil pengisian angket yang dilakukan pada setiap ulangan harian. Tindakan dikatakan berhasil apabila kriteria self-efficacy siswa meningkat jika dibandingkan dengan kondisi awal. Cara menghitung persentase self-efficacy siswa dan kualifakasi persentase self-efficacy siswa (Fitriana, 2015:95)

Persentase skor jawaban

$$
=\frac{\text { Skor jawaban }}{\text { skor maksimal }} \times 100 \%
$$

Tabel 3. Kualifikasi persentase selfefficacy siswa

$\begin{array}{ccc}\text { NO } & \text { Persentase } & \text { Kriteria } \\ 1 & P \geq 80 \% & \text { Sangat Mandiri } \\ 2 & 60 \% \leq P \leq 80 \% & \text { Mandiri } \\ 3 & 40 \% \leq P \leq 60 \% & \text { Cukup Mandiri } \\ 4 & 20 \% \leq P \leq 40 \% & \text { Tidak Mandiri } \\ 5 & P \leq 20 \% & \text { Sangat Tidak } \\ & & \text { Mandiri }\end{array}$

\section{Hasil dan Pembahasan}

Tindakan yang dilaksanakan pada penelitian ini adalah pembelajaran kooperatif teknik NHT. Pembelajaran ini disajikan dalam dua siklus sebanyak delapan kali pertemuan, sedangkan alokasi waktu dalam penelitian ini ialah dua kali pertemuan dalam satu minggu yang setiap kali pertemuannya $2 \times 40$ menit.

\section{Siklus 1}

Berdasarkan hasil pengamatan pada pertemuan pertama ini, pengamatan aktivitas guru dan siswa, proses pembelajaran yang dilakukan dengan menerapkan pembelajaran kooperatif tipe NHT belum sesuai dengan yang direncanakan. Masih banyak kelemahan dan kekurangan yang ditemui. Seperti pengelolaan waktu yang kurang baik, diskusi kelompok yang belum berjalan dengan baik.

Pada pertemuan kedua, proses pembelajaran yang dilakukan dengan menerapkan pembelajaran kooperatif tipe 
NHT belum sesuai dengan yang direncanakan. Masih banyak kelemahan dan kekurangan yang ditemui. Seperti pengelolaan waktu yang kurang baik, diskusi kelompok yang belum berjalan dengan baik, dan bahasa LKS yang kurang komunikatif sehingga masih banyak siswa yang bingung utuk mengisi LKS. Peneliti belum optimal dalam usaha meningkatkan keaktifan siswa. Hal ini terlihat dari sedikitnya siwa yang memberikan tanggapan pada saat presentasi dan tidak adanya siswa yang memberikan kesimpulan pembelajaran hari ini. Selain itu, banyaknya siswa yang sibuk melanjutkan LKS mereka yang belum selesai pada saat presentasi sehingga tidak memperhatikan presentasi temennya. Untuk pertemuan selanjutnya peneliti perlu melakukan perbaikan proses pembelajaran agar lebih baik lagi.

Pada pertemuan ketiga, proses pembelajaran yang dilakukan dengan menerapkan pembelajaran kooperatif tipe NHT belum sesuai dengan yang direncanakan. Tetapi sudah ada mulai ada perbaikan dari dua pertemuan sebelumnya. Seperti sudah mulai bisa mengelola waktu dengan baik dan melaksanakan tahapan-tahapan dari NHT. Siswa juga sudah mulai ada yang mau memberikan kesimpulan diakhir pertemuan.
Berdasarkan hasil diskusi guru dengan pengamat bahwa hasil pengamatan yang dilakukan selama melakukan tindakan pada siklus I proses pembelajaran belum terlaksana dengan baik. Adapaun aktivitas peneliti yang masih perlu diperbaiki adalah sebagai berikut :

1. Dalam pelaksanaan kegiatan pembelajaran, pengawasan guru masih kurang sehingga masih ada siswa yang kurang serius, masih bekerja secara individual dan kurang aktif dalam kelompoknya.

2. Siswa dalam mengerjakan LKS hanya mengaharapkan jawaban dari temannya tanpa mendiskusikanya. Sementara guru tidak mengetahui ada beberapa siswa yang kurang paham.

3. Guru masih ada tidak menyampaikan motivasi dan tujuan pembelajaran.

4. Guru kurang efisien dalam memanfaatkan waktu.

\section{Siklus 2}

Berdasarkan pengamatan pada pertemuan kelima, aktivitas guru dalam menerapkan model pembelajaran ini masih terdapat sedikit kekurangan, dimana guru masih kurang bagus dalam menjelaskan kepada masing - masing kelompok, sehingga masih ada kelompok yang masih bingung. Berdasarkan pada aktivitas siswa, diperoleh masih ada siswa 
yang tidak memperhatikan dan mendengarkan penjelasan guru tentang tujuan pembelajaran, serta masih belum berani untuk menanggapi hasil diskusi dari kelompok lain, tetapi siswa sudah mulai aktif bekerja sama kelompok mereka.

Berdasarkan pengamatan pada pertemuan keenam dan ketujuh, semua proses pembelajaran baik dilihat dari aktivitas guru dan aktivitas siswa sudah berjalan dengan baik. Pada kegiatan awal [pembelajaran, guru menyampaikan apersepsi, motivasi dan tujuan dari pembelakaran. Pada kegiatan inti juga guru sudah merata dalam membimbing siswa di dalam kelompoknya masingmasing. Untuk kegiatan akhir, siswa sudah banyak yang ingin menyampaikan apa-apa saja kesimpulan dari materi yang telah diperolehnya.

\section{Analisis Data Kuantitatif}

\section{Analisis Persentase Tes}

Kemampuan

Komunikasi

Matematis Siswa Setiap Indikator dan Jumlah Siswa Untuk Setiap Kategori

Peningkatan kemampuan

komunikasi matematis dapat dilihat dari analisis kemampuan komunikasi matematis untuk setiap indikator dan jumlah siswa untuk setiap kategori, yakni pada indikator kemampuan komunikasi matematis dan jumlah siswa untuk setiap kategori pada skor dasar, siklus I dan siklus II.

Adapun analisis kemampuan komunikasi matematis siswa dari skor dasar, UH I dan UH II adalah sebagai berikut:

Tabel 4: Analisis Kemampuan Matematis Siswa pada skor Dasar, UH I dan UH II

Nilai Skor UH I UH II Dasar

$\begin{array}{cccc}\text { Persentase } & 40 & 48,75 & 73,75 \\ \begin{array}{c}\text { Indikator 1 } \\ \text { Persentase }\end{array} & 33,75 & 46,25 & 75 \\ \begin{array}{c}\text { Indikator 2 } \\ \text { Persentase }\end{array} & 37,5 & 51,25 & 72,5 \\ \begin{array}{c}\text { Indikator 3 } \\ \text { Persentase }\end{array} & 36,26 & 43,75 & 70 \\ \begin{array}{c}\text { Indikator 4 } \\ \text { Rata - rata } \\ \text { Persentase } \\ \text { KKM }\end{array} & 36,87 & 47,5 & 72,81 \\ \text { Kategori } & \text { Rendah } & \text { Cukup } & \text { Tinggi }\end{array}$

KKM : Kemampuan Komunikasi

Matematis

\section{Sumber : Data olahan peneliti}

Berdasarkan tabel 4 tersebut dapat dilihat bahwa untuk semua indikator mengalami peningkatan persentase kemampuan komunikasi matematis. Dari skor dasar meningkat sebanyak 10,63\% ke UH I. sedangkan dari UH I ke UH II mengalami peningkatan sebanyak $25,31 \%$. 
Tabel 5 : Jumlah Siswa untuk setiap Kategori pada skor dasar, UH 1 dan UH

\section{II}

\begin{tabular}{|c|c|c|c|c|}
\hline Persentase & $\begin{array}{c}\text { Kategor } \\
\text { i }\end{array}$ & $\begin{array}{c}\text { Skor } \\
\text { Dasa } \\
\text { r }\end{array}$ & $\begin{array}{c}\mathrm{U} \\
\mathrm{H} \mathrm{I}\end{array}$ & $\begin{array}{l}\mathrm{U} \\
\mathrm{H} \\
\mathrm{II}\end{array}$ \\
\hline $\mathrm{P} \geq 80 \%$ & $\begin{array}{l}\text { Sangat } \\
\text { Tinggi }\end{array}$ & 0 & 1 & 8 \\
\hline $\begin{array}{c}60 \% \leq \mathrm{P}< \\
80 \%\end{array}$ & Tinggi & 0 & 4 & 10 \\
\hline $\begin{array}{c}40 \% \leq \mathrm{P}< \\
60 \%\end{array}$ & Cukup & 7 & 8 & 2 \\
\hline $\begin{array}{c}20 \% \leq \mathrm{P}< \\
40 \%\end{array}$ & Rendah & 10 & 7 & 0 \\
\hline $\mathrm{P}<20 \%$ & $\begin{array}{l}\text { Sangat } \\
\text { Rendah }\end{array}$ & 3 & 0 & 0 \\
\hline Juml & & 20 & 20 & 20 \\
\hline
\end{tabular}

Kemampuan Komunikasi Matematis

Siswa

\section{Sumber : Data olahan penelitian}

Berdasarkan tabel 5 di atas dapat dilihat bahwa untuk kategori sangat rendah pada skor dasar terdapat 3 orang siswa, pada UH I dan UH II tidak terdapat siswa yang memiliki kemampuan sangat rendah. Pada skor dasar tidak ada siswa yang berada pada kategori tinggi, Pada UH I terdapat 4 orang siswa dan pada UH II terdapat 10 orang siswa. Untuk kategori sangat tinggi pada skor dasar tidak ada siswa yang berada pada kategori ini, pada UH I terdapat 1 orang siswa dan pada UH II terdapat 8 orang siswa.

\section{Analisis Peningkatan Self-Efficacy} Siswa

Peningkatan self-efficacy siswa pada siklus I dan siklus II dilihat dari hasil skor ulangan harian I ke ulangan harian II siswa kelas VIII Mts YKWI Pekanbaru.

Tabel 6. Kualifikasi Tingkat SelfEfficacy Siswa Pada Ulangan Harian Siklus I dan Siklus II

$\begin{array}{ccc} & \text { UH I } & \text { UH II } \\ \text { Jumlah Skor } & 1092 & 1544 \\ \text { Persentase } & 54,6 \% & 77,2 \%\end{array}$

$(\%)$

Kategori $\quad \begin{gathered}\text { Cukup } \\ \text { Mandiri }\end{gathered}$

Berdasarkan analisis self-efficacy siswa pada tabel di atas artinya terjadi peningkatan dari skor dasar ke ulangan harian I ke ulangan harian II. Rata-rata persentase Self-Efficacy siswa secara keseluruhan mengalami peningkatan dari siklus 1 dan siklus 2. Pada siklus 1 didapat Self-Efficacy siswa sebesar 54,6\% yaitu kategori cukup mandiri. Pada siklus 2 didapat Self-Efficacy siswa sebesar 77,2\% yaitu kategori mandiri. Berdasarkan analisis tersebut dapat dikatakan bahwa self-efficacy siswa dapat ditingkatkan melalui pembelajaran kooperatif tipe Numbered Head Together (NHT).

\section{Pembahasan Hasil Penelitian}

Dengan berpedoman pada data kualitatif yaitu lembar pengamatan aktivitas guru dan siswa terjadi peningkatan pada aktivitas guru dan siswa pada setiap siklusnya hal ini ditandai dengan adanya perbaikan-perbaikan yang dilakukan guru pada setiap pertemuannya. 
Pada saat proses pembelajaran berlangsung guru selalu memberikan kesempatan kepada semua kelompok untuk berdiskusi dalam menemukan konsep serta mengerjakan segala perintah yang ada dilembar kerja siswa. Kemudian ketika ada siswa yang mengalami kesulitan guru berusaha memberikan bimbingan dan arahan dalam memberi penyelesaian dari masalah yang dialami siswa.

Sedangkan dari sikap siswa sudah terlihat adanya motivasi yang baik dalam belajar, setiap siswa berusaha dapat berperan aktif dalam setiap kegiatan pembelajaran dan pada saat melakukan diskusi di dalam kelompok. Siswa sudah menjalankan tugasnya masing-masing dengan baik sehingga pada saat penyajian hasil kerja kelompok siswa terlihat bersemangat dan berlomba-lomba agar dapat menjadi perwakilan kelompoknya dalam mempresentasikan hasil diskusinya.

Sementara itu, dengan adanya analisis data kuantitatif baik melalui analisis keberhasilan tindakan dapat diketahui bahwa terjadi peningkatan terhadap kemampuan komunikasi matematis siswa. Hal ini dapat di lihat dengan membandingkan skor sebelum tindakan dan sesudah tindakan. Persentase pada skor dasar adalah 36,51 \% dan mengalami peningkatan pada ulangan harian I yakni 56,25 \% kemudian juga mengalami peningkatan pada ulangan harian II menjadi $61,67 \%$. Untuk selfefficacy juga mengalami peningkatan dari siklus 1dan siklus 2. Pada siklus 1 diperoleh $54,6 \%$ dan pada siklus 2 diperoleh $77,2 \%$.

Dengan adanya perbaikanperbaikan yang terjadi dari aktivitas guru dan siswa maupun peningkatan kemampuan komunikasi matematis siswa sehingga dapat dikatakan bahwa pembelajaran kooperatif tipe NHT merupakan salah satu alternatif untuk menciptakan lingkungan belajar yang kondusif dengan membangun komunikasi interaksi yang baik antara guru dan siswa sehingga dapat meningkatkan kemampuan komunikasi matematis siswa.

Berdasarkan pembahasan hasil penelitian di atas, dapat disimpulkan bahwa penerapan pembelajaran kooperatif tipe NHT dapat memperbaiki proses pembelajaran dan meningkatkan kemampuan komunikasi matematis siswa. Jadi, analisis inimendukung hipotesis tindakan yang diajukan yaitu penerapan pembelajaran kooperatif tipe $\mathrm{NH}$ dapat memperbaiki proses pembelajaran dan meningkatkan komunikasi matematis siswa kelas VIII MTs YKWI Pekanbaru pada materi relasi dan fungsi. 
01, No. 2 September 2015 : 86101.

\section{Kesimpulan}

Berdasarkan penelitian dan pembahasan yang telah dikemukakan di atas, maka kesimpulan dari penelitian ini 1,1

AdMathEdu | Vol.8 No.2| Desember 2018 tוpe Ivumperea Heaas logetner (INHI) dapat meningkatkan kemampuan komunikasi matematis dan self-efficacy siswa kelas VIII Mts YKWI Pekanbaru pada materi relasi dan fungsi.

\section{Ucapan Terima Kasih}

Penulis mengucapkan terima kasih kepada pihak Mts YKWI Pekanbaru, serta pihak LPPM Universitas Islam Riau yang telah mensponsori tulisan ini untuk dilaksanakan. Serta seluruh rekan-rekan, akademisi, mahasiswa-mahasiswa dan semua pihak yang telah membantu dalam penelitian ini.

\section{Pustaka}

Arikunto,S dkk.2012. Penelitian Tindakan Kelas. Jakarta : PT. Bumi aksara

Fauzan, A. 2012. Modul Evaluasi Pembelajaran Matematika. Evaluasi matematika.net: UNP

Fitriana, S., dkk. 2015. Pengaruh Efikasi Diri, Aktivitas, Kemandirian Belajar dan Kemampuan Berpikir Logis Terhadap Hasil Belajar Matematika Pada Siswa Kelas VIII SMP. Journal Of EST. Vol.
Ilhamsyah, S. 2014. Pengaruh Efikasi Diri, Metakognisi dan Regulasi Diri Terhadap Prestasi Belajar Matematika Siswa Kelas X SMA Negeri Di Kabupaten Wajo. Journal Keguruan dan Ilmu Pendidikan (IKID) Vol n1 No 1 Penerapan ... (Putri)

Rahayu, I. 2014. Penerapan Model Pembelajaran Kooperatif Tipe Numbered Head (NH) Untuk Meningkatkan Kemampuan Komunikasi Matematis Siswa Kelas VIII 1 SMP Muhammadiyah 2 Pekanbaru. Skripsi pada FKIP UIR: Tidak Diterbitkan. 
